
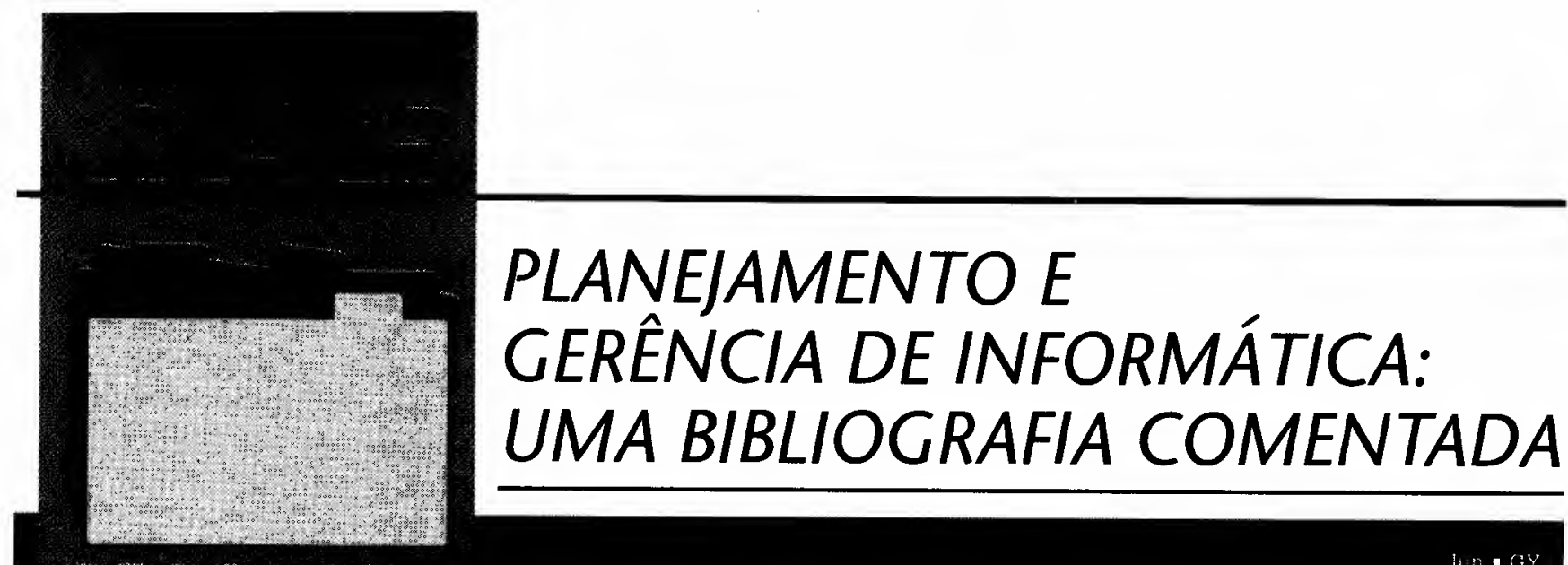

\title{
PLANEJAMENTO E GERÊNCIA DE INFORMÁTICA: UMA BIBLIOGRAFIA COMENTADA
}
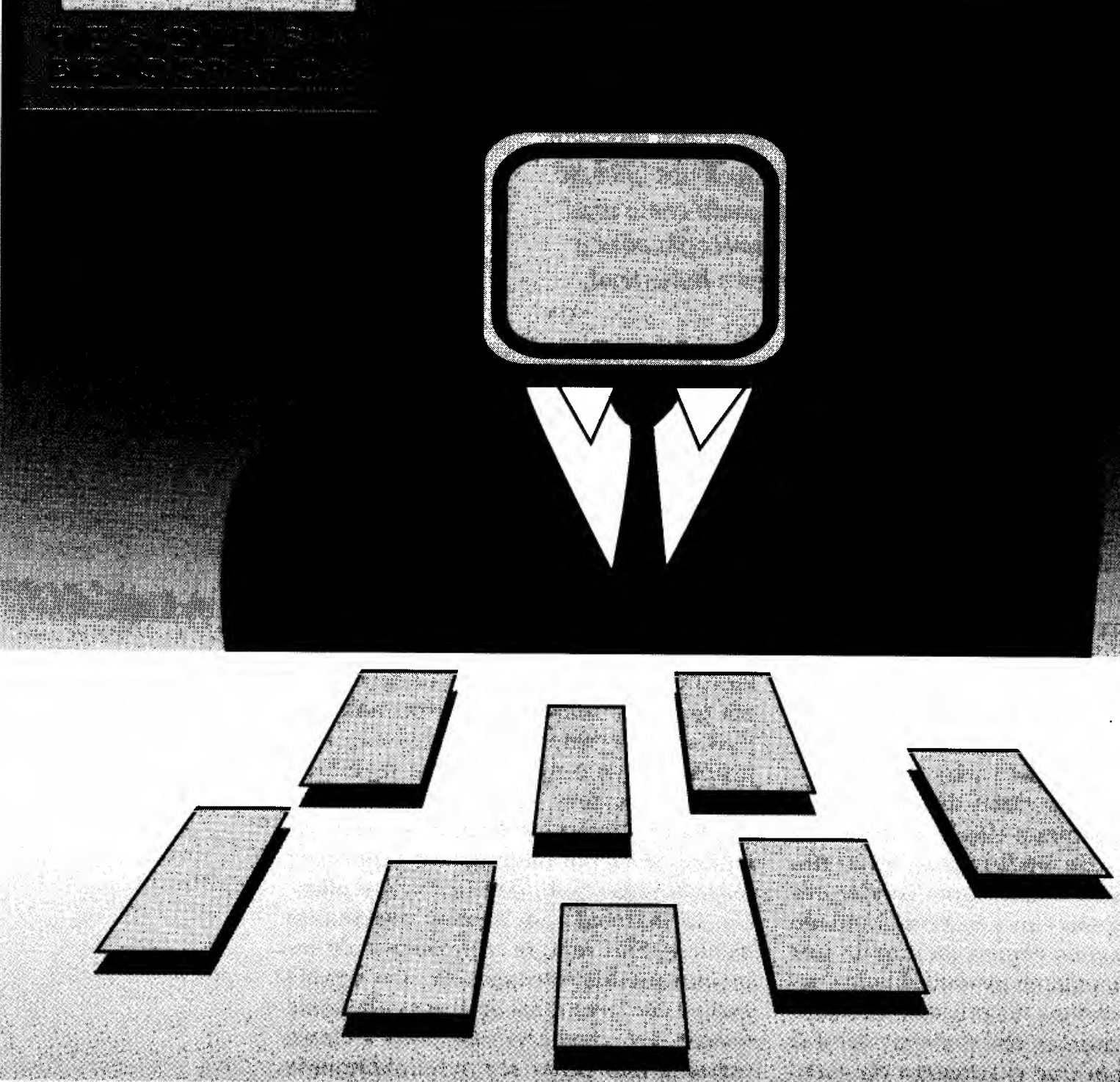

Antonio Carlos M. Mattos

Professor do Departamento de Informática e Métodos Quantitativos da EAESP/FGV.

Não há área na empresa que esteja passando por alterações rápidas e profundas como o setor de informática. O computador tem modificado o comportamento das pessoas, a forma de administrar as empresas e até mesmo a própria empresa, tornando obsoletas aquelas que ainda insistem em formas tradicionais de gerência. Hoje, um executivo de informática que não procura se atualizar mensalmente sobre os progressos da área, está condenado à aposentadoria precoce. Será rapidamente substituído por outro profissional que esteja a par das últimas novidades, não só a nível de hardware e software, mas também a nível de técnicas administrativas.

Esta pesquisa bibliográfica procura, dessa forma, fornecer um conjunto de informações atualizadas sobre o tema Planejamento e Gerência de Informática na empresa, que todo executivo de informática deve co- 
nhecer para poder bem gerir sua área. Está baseado em uma bibliografia selecionada e comentada, obtida nas melhores fontes disponíveis, e voltada para os microcomputadores. Pois foram estes guerrilheiros do tradicional Centro de Processamento de Dados que conseguiram, nos últimos anos, fazer com que equipamentos de milhões de dólares - os mainframes - fossem transformados em relíquias de museu, ao provocar o fenômeno do downsizing. A revolução foi tão grande que até mesmo a empresa líder do setor - a Big Blue - acabou por entrar, pela primeira vez em sua história, no vermelho, provocando um verdadeiro vendaval em sua estrutura corporativa, a ponto de Dvorak perguntar: " $A$ anarquia está em marcha na IBM, ou a empresa que fez o mainframe tem planos radicais para of futuro?".

Um outro terremoto (embora menos notado), que também se processa nos dias de hoje no setor, é a revolução ocorrida no cargo de Gerente de Sistemas, que se transforma em um mais nobre, o de Chief Information Officer (CIO, Executivo Principal de Informações). Para entender melhor essa transformação, é preciso analisar rapidamente o processo histórico em que está inserida essa mudança.

Com o advento da Revolução Industrial, surgiu também a primeira tentativa de tornar a administração algo mais científico e menos empírico, aleatório e pessoal. Taylor, um engenheiro industrial, com seu Principios de Administração Científica, publicado no início do século, procurou dar uma forma mais organizada aos processos industriais e burocráticos das empresas. Essa racionalização, também aplicada ao processamento das informações, deu origem à área de Organização e Métodos (O\&M) que, embora tenha quase um século de existência, ainda perdura em muitas empresas brasileiras de hoje.

Mas, com a introdução do computador nas organizações, nos anos 60, e a conseqüente mudança da forma de tratar e distribuir os dados, essa área foi condenada ao ostracismo, sendo substituída pela área de processamento de dados (PD). No entanto, o conflito O\&M x CPD, embora já ultrapassado nos países desenvolvidos, ainda existe entre nós. O enfoque do Gerente do CPD era o de automatizar as rotinas burocráticas, minimizar os custos, desenvolver programas rápidos e eficientes etc.

Nos anos 80, com o lançamento do primeiro microcomputador para uso profissional pela IBM (1981), os usuários, até então mantidos afastados e totalmente dependentes do CPD, começaram a vislumbrar a possibilidade de adquirir uma máquina de uns poucos mil dólares e usá-la para resolver os problemas de seu departamento, literalmente mandando o pessoal do CPD para o inferno. Hoje, naturalmente, isto já é rotina, sendo comum verem-se profissionais carregando seus próprios notebooks nos aviões. Isto, como era de se esperar, provocou outra revolução na empresa. Os usuários se unem e criam o Centro de Informações, ou seja, o seu próprio CPD, só que agora constituído pelos microcomputadores espalhados na empresa. Esse golpe foi mortal, e os jornais americanos mostram que o número de Gerentes de CPD desempregados está aumentando. Também o CPD está sumindo, surgindo em seu lugar a área de Informática, de relacionamento mais eqüidistante entre os mainframes e os micros.

Mas os vendavais não pararam por aí. Com mainframes ou com micros, os investimentos e os custos na área de Informática sempre foram altos, da ordem de vários milhões de dólares. Ora, valores dessa ordem sempre levam os acionistas a perguntar: "Que retorno isto está me dando?", ou, mais precisamente, "Em que medida esses altos investimentos estão tendo um retorno satisfatório em termos de lucratividade?". O pessoal da área de Informática, normalmente oriundo de escolas de engenharia, física ou matemática, não conseguia entender direito o significado empresarial de Retorno de Investimento. Suas análises e justificativas sempre enfatizavam o "gastar menos" (redução de custos), maior eficiência no uso do computador, maior rapidez no fluxo de informações etc., transformando a conversa muitas vezes em diálogo de surdos.

Foi aí que entrou a figura do Chief Information Officer. Esse novo executivo da área de informática tem por preocupação principal fazer com que os sistemas sejam utilizados de modo a aumentar a competitividade e a lucratividade da empresa. Ou seja, a tradicional Análise de Sistemas (System Analysis), um fim em si mesma, evolui para a Análise de Negócios (Business Analysis), onde o sistema agora se torna um meio de alavancar a empresa. Essa mudança de mentalidade ainda levará algum tempo para poder ser bem assimilada pelos profissionais de Informática, hoje ainda muito preocupados com metodologias de sistemas, otimização de redes, bancos de dados distribuídos e relacionais etc. e pouco sensíveis ao aumento da competitividade da empresa que toda essa tecnologia pode e deve produzir. $O$ observador atento também irá notar que esse novo perfil passa a excluir os engenheiros, físicos e matemáticos da área executiva, substituídos agora por profissionais oriundos de escolas de administração de empresas. Aliás, não é sem razão que um número cada vez maior desses profissionais está procurando os cursos de pós-graduação destas escolas.

Saviani, em seu primeiro livro no Brasil sobre CIO, cita dez características que esse novo executivo deve ter. Claro está que, por ser uma função nova, essa lista não é nem completa nem definitiva.

\section{- Ingrediente básico: o elemento humano}

$\mathrm{O}$ CIO deve se relacionar com as pessoas como seres humanos e não como meros "usuários de sistemas" (afinal, todos os funcionários são usuários). 
- A comunicação deve ser aberta e não criptografada No relacionamento com as pessoas, o CIO deve conhecer não somente a tecnologia da Informática, mas também os negócios em que a empresa está envolvida, de modo a poder entender os dois lados da questão: o sistema de informações e o departamento que o utiliza.

\section{- Gerenciamento das mudanças}

A informática provoca mudanças constantes no seio da organização, e o CIO deve ser hábil o bastante para saber administrá-las, sem pôr em xeque a sua cultura organizacional

- Integrante da alta direção

O CIO deve ser integrante da alta administração da empresa, e não um mero assessor ou conselheiro da Diretoria.

\section{- A tecnologia deve auxiliar e não atravancar} Os problemas que podem surgir com o uso do software e hardware não devem levar a impedimentos do tipo "isso não dá para fazer porque o computador não permite", mas devem ser resolvidos pelo CIO da melhor forma possivel.
- Deve promover mudanças e não acomodações

O CIO deve ser agente de mudança e de melhoria na empresa, e não apenas mais um burocrata.

\section{- As definições são dos usuários}

As alterações e mudanças a serem implementadas nos sistemas devem ser decididas pelos usuários. $O$ CIO deverá conciliar seus interesses com as possibilidades técnicas que o computador oferece.

\section{- A responsabilidade é da Diretoria}

O sucesso ou o fracasso dos sistemas implantados deve ser de responsabilidade da alta administração e não dos técnicos envolvidos.

\section{- Custo e benefício devem ter consenso geral}

Os custos dos sistemas são tangíveis e palpáveis, mas os benefícios são geralmente imponderáveis. As conclusões sobre as vantagens e desvantagens devem ser portanto consensuais, na falta de um instrumento de medida mais preciso.

\section{- Os sistemas devem ter auditados}

Os sistemas, uma vez implantados, não devem ser abandonados à própria sorte, mas devem sofrer um acompanhamento constante por parte do CIO.

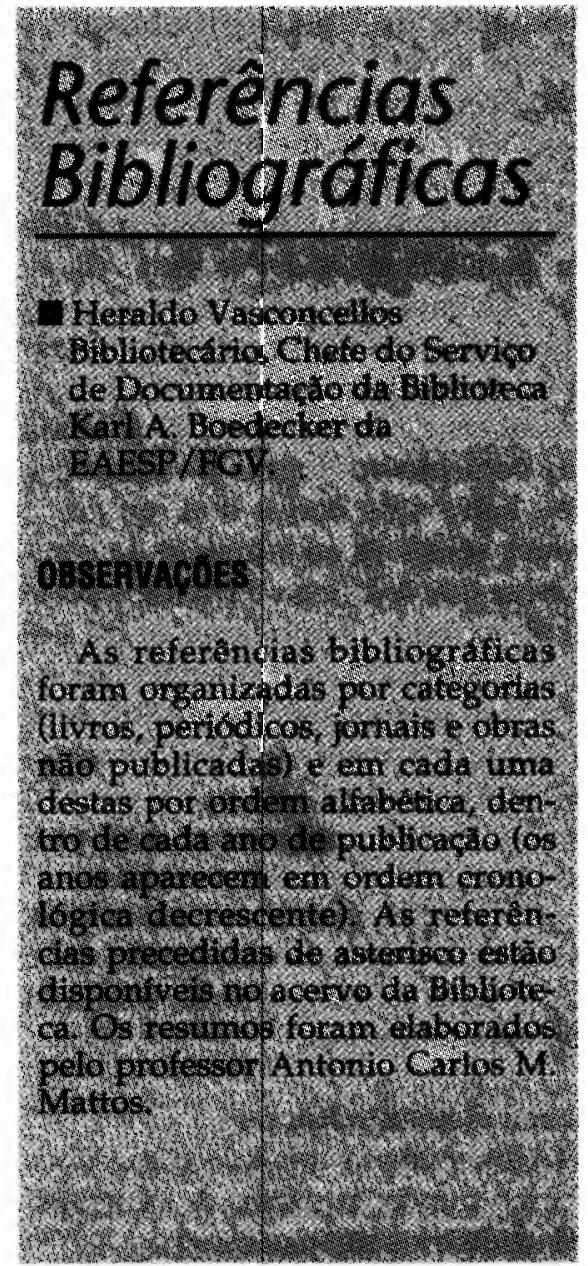

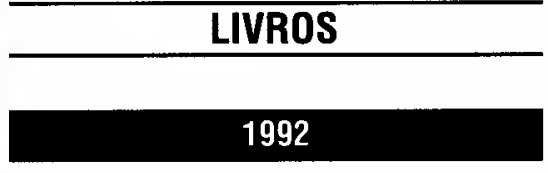

01. BLOOMBECKER, B. Crimes espetaculares de computação. São Paulo, LTC, 1992.

Mostra o que são e como chegam a custar meio bilhão de dólares por ano à economia americana. Relato ágil e bem humorado de alguns dos mais extraordinários crimes de computação cometidos sob as mais estranhas motivações, este livro constitui uma advertência. Leitura obrigatória para todos os profissionais que utilizam computadores no trato de qualquer coisa de valor - gerentes, auditores e contadores - bem como para projetistas, programadores e analistas de sistemas.

02. PFAFFENBERGER, B. Dicionário dos usuários de microcomputadores. Rio de Janeiro, Campus, 1992. 524p.

Embora com o nome de Dicionário, este livro é na realidade um glossário dos termos utilizados na microinformática, explicados na linguagem do usuário (e não do especialista). Contém uma lista em inglês-português. A tradução usa os termos normalmente empregados na área, ao contrário dos antigos dicionários elaborados por reservistas de mercado, onde hardware é traduzido por material, software por logicial, byte por octeto etc. (termos que ninguém usa), copiando o infantil purismo lingüístico do francês. Mais de 300.000 exemplares vendidos (nos
EUA). Edição americana de 1990. Um vademécum obrigatório na Era da Informática.

03. SAVIANI, J.R. O analista de negócios e da informação. Sāo Paulo, Atlas, 1992.

0 executivo responsável pela área de sistemas tem sofrido uma evolução, desde 0 aparecimento do computador. Originariamente um Chefe do Setor de Organização e Métodos, ele evoluiu para a fase do Gerente do CPD, e hoje está se transformando em um Chief Information Officer (ClO, ou Executivo Principal de Informática), seus subordinados são os Business Analysts (Analistas de Negócios). A principal diferença entre essa nova postura do profissional de Informática e a antiga (tipo Gerente do CPD), é que agora 0 executivo está preocupado em utilizar a Informática tendo em vista 0 aumento da competitividade da empresa, e não mais a mera redução dos custos com os formulários ou a otimização do uso da memória do computador. A origem desse novo enfoque é que os acionistas perceberam que os altos investimentos da área de sistemas deveria ter como retorno 0 aumento da lucratividade da empresa, ao invés de ser mais um centro de custo burocrático.

\section{0}

04. CIDALE, R.A. Virus digital. São Paulo, McGraw-Hill, 1990, 105p.

Aborda o problema dos vírus de forma mais técnica. No capítulo 6, faz autópsia de 
vários tipos de vírus, mostrando em detathe o seu funcionamento.

05. RODGERS, F.G. The IBM way. São Paulo, Harbra, 1990, 266p.

Desvenda aspectos inéditos da organização de marketing de maior sucesso no mundo, ajudando a entender por que a IBM domina os mercados de Informática e é a concorrente mais temida pelos fabricantes de computadores do Terceiro Mundo. No Brasil, suas vendas foram de US $\$ 1,5$ biIhões em 1991, contra US\$ 350 milhões para $02^{\circ}$ colocado (SERPRO).

\section{9}

06. GIL, Antonio de Loureiro. Auditoria de computadores. São Paulo, Atlas, 1989, 203p.

0 Prof. Gil, da FEA-USP, foi um dos pioneiros na introdução da Auditoria de Sistemas no Brasil, após o escândalo da Equity Funding americana, em 1973. Com efeito, essa fraude de US\$ 2 bilhões mostrou ao mundo que a profissão de auditor contábil já é coisa do passado na era da Informática, pois o crime só poderia ter sido descoberto por auditores de sistemas. Os desvios de dinheiro se passavam dentro do computador, e eram impossiveis de serem detectados pela simples análise convencional dos relatórios emitidos.

07. KANE, P. Virus protection. New York, Bantan Books, 1989, 477p.

Livro bastante completo sobre os vírus de computador, um dos maiores problemas de segurança da atualidade, pois não há nenhuma maneira absolutamente segura de preveni-los. Todo mês novos tipos de vírus são descobertos, e as vacinas para esses casos sempre chegam depois (uma das mais famosas vacinas, 0 vírus Scan da McAfee, em sua versão 91, de maio de 92 , contém inclusive um alerta para trocar 0 programa por versão mais recente, após decorridos sete meses). Contém disquete com programas de prevenção.

08. *TORRES, Norberto Antonio. Planejamento de Informática na empresa. São Paulo, Atlas, 1989, 218p.

Uma abordagem abrangente e didática sobre o tema, escrito pelo Professor da EAESP/FGV que há muitos anos atua em consultoria de Informática.

\section{8}

09. *CARVALHO, Luis Carlos de Sá. Análise de sistemas: o outro lado da Informática. Rio de Janeiro, Livros técnicos e Científicos/Sociedade Cultural e Beneficente Gui-
Iherme Guinle, 1988, 223p.

Os livros sobre análise de sistemas ensinam o que deve ser, deixando geralmente de lado como é na prática. Esta obra mostra 0 que é a análise de sistemas na realidade, os vícios mais comuns, e as medidas para saná-los, são temas incômodos para 0 analista, mas necessários, pois a primeira medida que deve ser tomada pelo administrador para resolver um problema é (embora nem todos saibam) conhecer 0 problema.

10. *MEIRELLES, Fernando de Souza. Informática: novas aplicações com microcomputadores. São Paulo, Makron, 1988, 444p.

0 Professor Meirelles, da EAESP/FGV, fornece uma abordagem bastante ampla sobre os micros e, principalmente, sobre a realidade brasileira, com base em um banco de dados bem atualizado por ele desenvolvido. Sua abordagem é prática e profissional, em oposição aos enfoques teóricos e acadêmicos.

\section{7}

11. NAVARRO, P.L.K.G. Centro de informações. Rio de Janeiro, Campus, 1987, 111p.

Os Centros de Informações (Cl), conceito criado pela IBM na década de 70 , visa a estabelecer um local onde as pessoas leigas em Informática usam o computador diretamente, sem intermediários. $0 \mathrm{Cl}$ foi resultado da disseminação dos micros entre os usuários, agora não mais dependentes do tradicional Centro de Processamento de Dados (CPD) para resolver os seus problemas, que podem ser encaminhados diretamente ao $\mathrm{Cl}$, que nada mais é que seu próprio clube. Naturalmente, o pessoal do CPD tem custado a engolir essa pilula.

12. OLIVEIRA JR., J. O caos vem computadorizado. São Paulo, Cartograf, 1987, 7.

Os cursos e os livros de administração de Informática quase sempre abordam apenas como deve ser gerenciada a área de sistemas na empresa, mas raramente mostram como é na prática. As metodologias de sistemas quase nunca são seguidas, 0 planejamento é quase inexistente, a seleção de pessoal é feita sem muitos critérios, a competência administrativa é substituída pela competência matemática etc. 0 resultado disso tudo, também quase nunca mencionado, é o caos.

Não são poucos os casos de empresas que quase fecharam seu CPD, ou que trocaram os seus funcionários, por terem chegado a uma situação insustentável na área de Informática. Esta é a novidade deste livro. Ao abordar, de uma forma prática e realista, 0 que ocorre em grande parte das empresas brasileiras, 0 autor levanta um alerta, ao concluir sua exposição: $P l a-$ neje e administre com competência. Fora isso, só resta gritar: Socorro, comprei um computador!

\section{9}

13. ${ }^{*}$ KORDA, Michael. 0 jogo do poder na empresa. Rio de Janeiro, Francisco Alves, 1979, 238p.

Por que, na empresa, os que são promovidos não são necessariamente os mais competentes? Por que aqueles que mais se esforçam nem sempre são reconhecidos? Por que um funcionário que dedicou vários anos à sua organização é sumariamente despedido e substituído por outro recém chegado? Este livro, um best-seller americano, tem uma resposta simples a essas questões: a promoção é um jogo - o Jogo do Poder - e somente quem sabe jogá-lo pode subir na hierarquia.

0 autor procura descrever em detalhes as regras desse jogo obscuro, depois de conviver por vários anos ao lado do poder, observando todos os pequenos detalhes que geralmente passam despercebidos, como um sapato engraxado, uma mesa num local escondido e sombrio, ou as mãos sempre vazias.

Na presente Bibliografia, esta é a única referência que não faz parte do tema Informática, mas foi aqui incluída porque de nada adianta o conhecimento dos assuntos abordados, se eles não puderem ser colocados em prática. $E$ isto só é possível para aqueles que detêm algum poder de mando na organização.

\section{7}

14. *PARKER, Donn B. Crime por computador. Rio de Janeiro, Agents, 1977, 259p.

Esta foi a primeira obra a abordar sistematicamente 0 problema das fraudes e furtos de dinheiro através do computador (crime do colarinho branco), assunto que tomou conta dos jornais pela primeira vez no mundo em 1973, com a falência da Equity Funding, que provocou um rombo de 2 biIhões de dólares, a segunda maior da história econômica americana.

No capítulo 7, o autor procura traçar 0 perfil do fraudador, geralmente com idade entre 18 a 30 anos. Embora o livro já seja antigo (quase não havia microcomputadores na época, só mainframes) o problema levantado no livro continua bastante atual. É uma obra clássica sobre o assunto. 


\section{6}

15. PARKER, Donn B. Crime by computer. New York, Charles Scribner's Sons, 1976. (Ver referência $n^{0} 14$.)

\section{5}

16. “KORDA, Michael. Power! How to get it, how to use it. New York, Random House, 1975, 268p. (Ver referência no 13.)

\section{PERIODICOS}

\section{2}

17. *BRIEFS. PC Magazine, Boulder, 11(4):32, Feb. 251992.

Nessa nota, a revista alerta os usuários para que, em se tratando de vírus, desconfiem também dos disquetes originais fornecidos pelos fabricantes de software. em dezembro de 91, a Novel, fornecedora de sistemas operacionais para redes LAN, enviou carta a cerca de 3.800 clientes, alertando-os para o fato de que alguns de seus disquetes originais haviam sido infectados pelo vírus Stoned III.

18. *DERFLER JR., Frank J. Connectivity simplified. $P C$ Magazine, Boulder, 11(6):251-2+, Mar. 311992.

A tendência é que todos os micros trabalhem em rede. Nesse artigo 0 autor explica, de forma simplificada, todos os conceitos relativos às redes de micros.

19. *DVORAK, John C. Inside track. PC Magazine, Boulder, 11(11):95, June 161992.

0 que existe por trás da compra da Fox Software pela Microsoft? Esta operação visa a enfraquecer a Borland, obrigando-a a alocar recursos limitados tanto ao Paradox como ao dBase.

Obs.: 0 mercado de bancos de dados, a terceira maior aplicação dos micros, está hoje na mão dessas duas empresas concorrentes.

20. *DVORAK, John C. New stealth viruses: a menace to users. PC Magazine, Boulder, 11 (7):93, Apr. 141992.

Os programadores da ex-URSS e da Bulgária, talvez por não terem 0 que fazer, desenvolveram três novas tecnologias para os vírus, que já causou muitos problemas nos EUA, pois os detectores existentes não conseguiam identificá-los. Trata-se dos vírus Stealth (furtivos), polimórficos e multipartites. 0 autor sugere dois softwares que, em suas últimas versões, já conseguem atenuar os efeitos: o Vírus Scan da
McAfee versão 91 de maio de 92, e o Novi da Certus. Quando surgem novas gerações de vírus, como foi o caso, todos os programas anti-virus existentes podem ser descartados.

21. *DVORAK, John C. The software piracy bluff. PC Magazine, Boulder, 11(9):93, May 121992.

Os fabricantes de software alegam prejuizos de US $\$ 10$ bilhões por ano com a pirataria, para um faturamento de igual valor. Ou seja, a cada dólar vendido, um dólar é pirateado. Na lista dos maiores piratas, estão em primeiro lugar a Alemanha, seguida da Itália e Taiwan. Mas, Dvorak mostra que essa indústria já está ganhando muito, usando o exemplo do proprietário da $\mathrm{Mi}$ crosoft, Bill Gates, o homem mais rico dos EUA (patrimônio pessoal de US\$ 7 bilhões em 15 anos, ou 1,3 milhões por dia) e pergunta: Afinal, quem está roubando quem? Se os usuários resolvessem adquirir as alternativas mais baratas vendidas em regime de shareware (onde uma planilha eletrônica custa US\$20) a indústria de software seria obrigada a baixar seus altos precos, e o prejuizo seria maior.

Obs.: No Brasil, a Maple Informática vende nas bancas de jornais software americano obtido em regime de shareware.

22. *DVORAK, John C. Will IBM dump the mainframe? PC Magazine, Boulder, 11 (11):93, June 161992.

A IBM está sofrendo profundas reorganizações em sua estrutura. Seus departamentos foram transformados em empresas autônomas sob controle da holding. Por outro lado, há a tendência do downsizing, onde os mainframes estão sendo substituídos por redes de micros, ou pelos minis Risk da própria IBM. Nesse quadro, Dvorak pergunta: "A anarquia está em marcha na $I B M$, ou a empresa que fez o mainframe tem planos radicais para o futuro?" Em outras palavras, a IBM vai jogar o mainframe no lixo? Parece que ela pretende se dedicar apenas a tecnologias de ponta e viver de suas patentes, de acordo com o velho jogo: patentes, processos judiciais, licenciamento, processos, lucros, mais processos.

23. *FERSKO-WEISS, Henry. Project management software gets a grip on usability. $P C$ Magazine, Boulder, 11(13):323-6+, July 1992.

Um benchmark com oito softwares para a administração de projetos é realizado. Os escolhidos sã̃o o MS Project for Windows 3.0 e o Time Line 5.0 .

24. *JONES, M. From print to PC: OCR gets you from there to here. PC Magazine, Boulder, 11(13):267-71+, July 1992.

A profissão de digitador (operador de data-entry) tende a desaparecer, substitui- da pelo Scanner (hardware que grava uma folha de papel com textos e gráficos no disco) e pelo OCR (Optical Character Recognition, software que converte o texto do formato gráfico TIF para formato ASCII, efetuando uma leitura e interpretação das letras fotografadas pelo Scanner). Um Scanner e um OCR podem ser adquiridos por US\$1.500. A revista analisa 9 OCRs e escolhe como os melhores o OmniPage Professional 2.0 e o WordScan Plus 1.1.

25. *MENDELSON, Edward. 7 windows Word processors. PC Magazine, Boulder, 11(4):113-16+, Feb. 251992.

São analisados sete processadores de texto para 0 ambiente Windows. Os escolhidos como melhores são o Ami Pro 2.0 da Lotus e 0 Word for Windows 2.0 da Microsoft.

26. *MILLER, Michael J. Windows enters its prime; $O S / 2$ is a fascinating technology but a dubious challenger. $P C$ Magazine, Boulder, 11(8):113-14+, Apr. 281992.

Coincidindo com o lançamento do Windows 3.1 pela Microsoft, este artigo fornece uma visão detalhada das características dessa nova versão de interface gráfica, comparando-a também com o sistema operacional OS/2 2.0 da IBM.

27. *QUAIN, J.R. Power gets cheaper. PC Magazine, Boulder, 11(3):113-16+, Feb. 11 1992.

0 microcomputador mais rápido atualmente é o baseado no chip 486DX de 33 $\mathrm{MHz}$ da Intel, podendo chegar a $66 \mathrm{MHz}$, com 0 chip dobrador de freqüência. No artigo, são analisados 24 modelos dessa máquina. Os escolhidos pelo laboratório da PCM foram o Austin 486/33i Winstation para ambiente Windows (US\$2.700), o Tangent $433 \mathrm{e}$, EISA bus para trabalhar como servidor de rede (US\$5.000) e 0 Zeos 486-33 para DOS (US\$3.500).

28. ${ }^{\star} \mathrm{ROSCH}$, Winn L. The perfect PC. PC Magazine, Boulder, 11(13):110-14, July 1992.

Um PC é constituído de vários componentes - gabinete, motherboard, placa de vídeo etc. - que podem ser adquiridos de vários fornecedores diferentes - Seagate, DTK, ATl etc. - e montados em inúmeras configurações alternativas. Tais PCs não têm marca de nenhum fabricante: não são um micro IBM, Zeos ou Compaq, e qualquer pessoa pode montá-los, desde que saiba escolher componentes compativeis em termos de performance (por exemplo, não adianta montar uma placa baseada no $486-33 \mathrm{com}$ um Winchester de $60 \mathrm{~ms}$ ). Esse artigo mostra exatamente como escolher os componentes, e sugere três configurações montadas e testadas: uma sem limite de custos (só considerada a performance), uma workstation para Windows, e uma econômica. 
29. *SEYMOUR, Jim. Platforms: how the PC stacks up. PC Magazine, Boulder, 11(9):133-17+, May 121992.

Há quem prefira Macintosh, outros NeXT, SUN, ou IBM-PC. Qual a melhor escolha? Os laboratórios da PC Magazine escolheram quatro representantes de cada uma das quatro plataformas e realizaram uma série de testes, mostrando o desempenho de cada uma.

0 Macintosh se destacou para trabalhos gráficos, desktop e multimidia. 0 Sun SPARCstation primou pela rapidez nos cálculos matemáticos. 0 NeXT combinou as características do Macintosh e do UNIX, além de seu design elegante. Mas o PC continuou como a melhor escolha, pois nenhuma outra plataforma conta com tão grande aceitação, uma vasta gama de opções de software os mais baixos preços. A tabela 1 mostra como 0 mercado está distribuído.

\section{Distribuição do mercado por plataformas}

(em $\%$ de unidades; $100 \%=9,8$ milhões de unidades instalada

\begin{tabular}{|l|r|}
\hline IBM-PC & 82 \\
\hline Macintoch & 13 \\
\hline Apple, Tandy etc. & 2 \\
\hline Motorola 68000 (neXT etc.) & 2 \\
\hline RISC (Sun, HP, IBM etc.) & 1 \\
\hline
\end{tabular}

\begin{tabular}{|c|c|}
\hline \multicolumn{2}{|r|}{$\begin{array}{c}\text { Produtos mais vendidos } \\
\text { no varejo } \\
\text { (última semana) }\end{array}$} \\
\hline 1 & Windows 3.1. Upgrade \\
\hline 2 & DOS 5.0 Upgrade \\
\hline 3 & QEMM-386 6.0 \\
\hline 4 & Windows 3.1 \\
\hline 5 & Word Perfect 5.1 for DOS \\
\hline 6 & Lotus 123 Home Edition for DOS \\
\hline 7 & Excel 4.0 for Windows \\
\hline 8 & True Type Pack for Windows \\
\hline 9 & Stacker 2.0 \\
\hline 10 & Excel 4.0 Upgrade for Windows \\
\hline 11 & Word 2.0 for Windows \\
\hline 12 & Procom Plus 2.1 \\
\hline 13 & Word Perfect 5.1 for Windows \\
\hline 14 & Word 2.0 Windows Upgrade \\
\hline 15 & MS C/C++ Compiler 7.0 Upgrade \\
\hline
\end{tabular}

30. *TOP retail software. PC Magazine, Boulder, 11 (13):31, July 1992.

Mensalmente, a revista PCM publica a relação dos softwares mais vendidos nos EUA, o que acaba ditando um padrão mundial. (Ver tabela 2.)

31. USED PCs: Cheaper than never, PC Magazine, Boulder,31, Sept. 1992.

0 preço dos PCs usados tem caído bastante. Um 386-SX, que custava US\$2.000 em 1989, custa US $\$ 775$ em 1992. 0 preço do AT-286 baixou de US $\$ 1.300$ para 500 , o XT-8088, de US\$ 800 para 200, no mesmo período. No Brasil, um XT usado, como de costume, custa três vezes mais.

32. "VENDITTO, Gus. Free at last: dBase future is secure. PC Magazine, Boulder, 11(3):30, Feb. 111992.

A compra da Ashton-Tate (dBase) pela Borland (Paradox) foi resultado da perda de uma ação judicial movida pela primeira contra a Fox-Software (Fox-Pro). 0 artigo mostra como ficaram os acordos finais na justiça. 0 dBASE não será descontinuado pela Borland.

33. *ZACHMANN, William F. Upgrade fever. PC Magazine, Boulder, 11 (3):107, Feb. 111992.

É próprio da cultura americana a avidez pela novidade e pela atualização. No software, isso se dá através de upgrades (por exemplo, trocar a versão 5.0 do MS Word pela versão 5.5). No hardware, pela modularidade (trocar um módulo da placa para aumentar a velocidade, desde que o módulo seja do mesmo fornecedor).

0 autor alerta para 0 fato de que esses upgrades às vezes são mera perfumaria de marketing, não trazendo nenhuma novidade relevante para 0 usuário, que gasta algumas centenas de dólares na troca pela nova versão. Os novos lançamentos às vezes são apenas uma forma de aumentar a lucratividade do fabricante, que trabalha com altas margens nos upgrades. Tal foi o caso do MS Word, onde a versão 5.5 (hoje vendida com um brinde: 0 analisador sintático Grammatick, pela loja ComputAbility, EUA) não trouxe nenhuma novidade, a não ser uma interface gráfica mais para Windows que para o Word 5.0. Desse modo, a febre do upgrade deve ser conduzida com cautela: 0 novo produto deve realmente ser dotado de inovações que justifiquem o empate de capital.

\section{1}

34. COMPAQ flops, HP tops in HP reliability studies. PC Week, Boston, Feb. 11 1991.

Interessante estudo, embora incômodo para alguns fabricantes, mostra a percentagem de microcomputadores que apresen- taram defeitos no primeiro ano de uso. (Ver tabela 3.)

35. *DVORAK, John C. Myth, mystique, mania and Microsoft. PC Magazine, Boulder. $10(7): 81$, Apr. 161991.

Como a Microsoft, líder mundial do mercado de software para PCs, tenta manter sua liderança, constantemente ameaçada pelos parceiros comerciais, lançando produtos semelhantes e com os números das versões também acompanhando os da concorrência, embora muitas vezes a nova versão do software seja apenas perfumaria (como ocorreu com o editor de textos MS-Word 5.5). É uma estratégia de marketing bem diferente da Lotus e da Ashton-Tate (dBase), que tentam manter a liderança processando judicialmente seus concorrentes.

36. 'EDITORS' choice: FoxPro, Paradox. PC Magazine, Boulder, 10(10):108, May 281991.

Um benchmark é realizado entre os softwares de banco de dados, sendo selecionados como os melhores o FoxPro (Microsoft em 1992), para o desenvolvimento de novos bancos de dados, e o Paradox 3.5 (Borland), para ser utilizado diretamente pelo usuário final, sem necessidade de se conhecer programação (embora também o permita). Ambos custam US\$ 795. 0 dBASE (Borland em 1992), líder do mercado, não foi recomendado por apresentar sérios problemas nos módulos QBE e SQL e em seu Control Center, além de não possuir vários recursos existentes em seus concorrentes. A revista cita também um processo judicial de novembro/88, onde a Ashton-Tate (proprietária do dBASE), ao invés de melhorar o produto para vencer a concorrência, resolveu acionar seu competidor, alegando que a FoxPro havia copiado seu produto patenteado. A Corte americana decidiu, em dezembro/90, que 0 copyright do dBASE era inválido, pois: 1. A Ashton-Tate omitiu dados importantes por ocasião da submissão do pedido de patente ao United States Copyright Office; 2. Copiou o dBASE de um outro produto de domínio público, 0 Jet Propulsion Laboratory Data Management and Information System (fato também omitido pela AshtonTate por ocasião do pedido de patente);

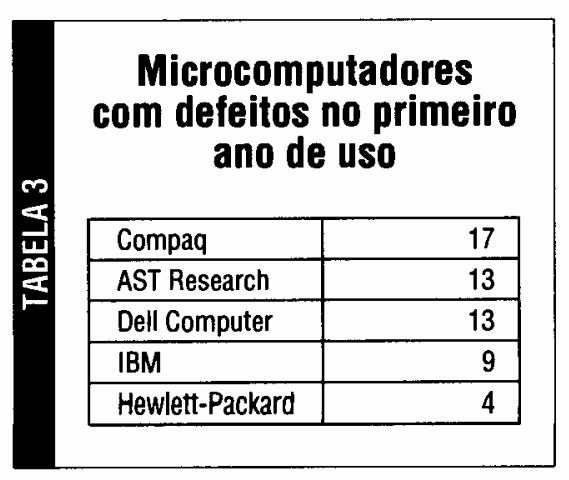


3. Participou e incentivou o desenvolvimento do FoxPro, em seus primórdios.

Obs.: Mais tarde, a Corte voltou atrás, mas à Borland já havia adquirido a Ashton-Tate, e um acordo entre esta e a Fox Software encerrou a disputa. Posteriormente, a Fox foi comprada pela Microsoft. Nessa briga, todos os contendores saíram perdendo. Ganharam os advogados.

37. ${ }^{\star}$ ELLISON, Carol. On guard: 20 utilities that battle the virus threat. $P C$ Magazine, Boulder, 10(18):199-201+, Oct. 291991.

Os laboratórios da $P C$ Magazine realizam um benchmark com 20 antivirus e escolhem os melhores: Central Point antivírus (do fabricante do PCTools) e Dr. Solomon's antivirus Toolkit.

Obs.: Mensalmente surgem cerca de quatro novos vírus no mundo. Assim, a rapidez com que um fabricante atualiza seu software pode tornar um dado produto rapidamente obsoleto.

38. *FORESTER, TOM \& MORRISON, Perry. A insegurança do computador e a vulnerabilidade social. Revista de Administração de Empresas, São Paulo, 31(4):73-83, out./dez., 1991.

Muitos têm mencionado que as sociedades industriais estão cada vez mais se tornando dependentes de tecnologia e assim se tornando mais vulneráveis às falhas tecnológicas. Não obstante à difusão da tecnologia do computador, pouco é conhecido sobre as suas falhas, exceto, talvez, que são muito comuns. Esse artigo analisa as origens da inconfiabilidade do computador e revê a extensão e o custo dos computadores inconfiáveis. Ao contrário de artigos já escritos anteriormente, os autores argumentam que os computadores são inerentemente inconfiáveis por duas razões: primeiro, são passíveis de falhas totais, ao invés de parciais; e, segundo, sua enorme complexidade significa que não podem ser amplamente testados antes de serem utilizados. Os autores descrevem várias tentativas institucionais para melhorar a confiabilidade e as possiveis soluções propostas pelos cientistas da computação, mas concluem que ainda são inadequadas. Em conseqüência, recomendam que os computadores não devem ser utilizados em aplicações onde haja risco de vida (hospitais, automóveis, aviões etc.).

39. *MATZKIN, Jonathan. Palmtop PCs: power by the ounce. PC Magazine, Boulder, PCM, jul-91, p. 19.

Últimas novidades em Palmtop calculators (calculadoras de mão, $2,5 \times 16 \times 8,4$ $\mathrm{cm} 3$ ), indicando a tendência do mercado. A HP lança a calculadora 95LX (US\$500), com tela de 16 linhas por 40 colunas, baseada em um processador NEC V-2OH (compativel com o 8088 do PC-XT), DOS $3.22,512$ KB de RAM, e Lotus 123 v.2.2 incluído). A calculadora por excelência do executivo (PCM Editors' Choice), obsoletando completamente o $P C-X T$, equipamento mais vendido no Brasil.

40. *MENDELSON, Edward. Scalable fonts for the PC. PC Magazine, Boulder, 10 (16):111-12+, Sept. 241991.

As alternativas para a escolha de tipos de letras para as impressoras a laser.

41. *NOCAUTE tecnológico. Veja, São Paulo, 24 (25):36-41, 19 jun. 1991.

Mostra como a reserva de mercado no Brasil serviu para mantê-lo atrasado no setor de Informática. Compara também o uso do computador em vários países. (Ver tabela 4.)

42. ${ }^{*}$ PASTRICK, Greg. 286 notebooks. PC Magazine, Boulder, 10 (5):226+, Mar. 12 1991.

Existematualmente oito tipos de computadores:

1. Supercomputadores (de grande porte $e$ extremamente rápidos, custando vários miIhões de dólares, como 0 da Cray Research);

2. Mainframes (de grande porte, acima de US\$ 500.000: IBM, CDC etc.);

3. Minis (um pouco menores, incluindo super-minis, super-micros etc., até uns US\$ 500.000: IBM, VAX, HP, DEC);

4. PCs (de mesa, a partir de US $\$ 500$, IBM e clones)

5. Laptops (portáteis, do tamanho de uma mala 007, já obsoletados pelos Notebooks, US $\$ 3.000$ : IBM e clones);

6. Notebooks (portáteis, do tamanho de um caderno grande, US\$2.000: IBM e clones);

7. Palmtops (do tamanho da palma da mão, US\$ 500: HP, Casio);

8. Calculadoras de bolso (US $\$ 300$ ou menos: HP, Casio).

Nesse artigo, a PCM analisa os Notebooks baseados nos microprocessadores 286 (do PC-AT) e 386 à venda no mercado, e seleciona como os melhores 286 (todos em torno de US $\$ 2.300$ ) os seguintes: CompuAdd Companion, Ogivar Internote
286, Sanyo MBC-17NB, Sharp PC-6220 TravelMate 2000 e Zeos Notebook 286 . Entre os baseados no 386, os melhores foram: Compaq LTE 386s/20 (US\$ 6.500), Dell 316LT e 320LT $(\$ 3.900)$, e Toshiba T3100SX (\$5.700).

Obs.: Em julho/92, um notebook 386SX-20 da ZEOS (PCM Editor's Choice) podia ser comprado por US $\$ 1.500$.

43. *PRINTER decision guide: what to buy. PC Magazine, Boulder, 10 (20):112, Nov. 261991.

Analisa os prós e contras, velocidade, preço, custo por página impressa, qualidade de impressão, cor, ruído de impressão, tamanho e tipo de papel, para impressoras do tipo matriz de pontos, jato de tinta, laser de mesa, laser compartilhada em rede, e postscript a cores, fornecendo úteis subsídios para a escolha do tipo de impressora.

44. *RAPPAPORT, A.S \& HALEVI, S. The computerless computer company. Harvard Business Review, Boston, 69(4):69, July 1991.

Este foi considerado por muitos como 0 melhor artigo publicado na Harvard em 1991, tendo recebido várias críticas e elogios, através de cartas dos leitores (publicadas na edição de set./91, p. 140). Basicamente, o paper argumenta que as empresas americanas não mais devem fabricar hardware para microcomputadores, pois a concorrência japonesa está fazendo com que a margem de lucro fique cada vez menor. Ao contrário, devem se dedicar a outros nichos de alta tecnologia, onde não haja concorrência, permitindo maiores margens.

Obs.: É interessante notar que o Brasil, com sua Reserva de Mercado, está justamente querendo concorrer com os EUA $e$ Japão nesse mercado. A idéia aqui só foi em frente porque os consumidores foram obrigados a pagar preços absurdos por equipamentos nacionais obsoletos, propiciando aos fabricantes grandes margens de lucro. $E$, ao que parece, a IBM pode seguir a linha descrita no artigo.

45.ROSCH, W.L. Choosing and using hard disks. PC Magazine, Boulder, 10(22):313, 
Dez. 311991.

Uma completa abordagem sobre a seleção e o uso de discos rígidos.

Obs.: Em 92 a HP lança um winchester do tamanho de uma caixa de fósforos, com $21 \mathrm{MB}$, por US $\$ 250$, para uso em nova série de Palmtops.

46. *SALEMI, Joe. Advisor. PC Magazine, Boulder, 10(16):460, Sept. 241991.

Informa sobre a existência de um software de tradução automática, Globalink Translation System, para as línguas espanhola, francesa, alemã, italiana, portuguesa e russa. É especializado em textos científicos, técnicos e legais. Custa US\$2.000.

47. *SEYMOUR, Jim. How Microsoft blew it with Word 5.5. PC Magazine, Boulder, 10 (8):87-8, Apr. 301991.

Quando o usuário se acostuma com um software, por exemplo, o editor de textos Word 5.0, qualquer versão ulterior deve manter a mesma interface, pois do contrário o usuário não irá querer realizar um upgrade (mudar para uma versão mais nova), já que teria que reaprender a utilizar o programa, 0 que é bastante penoso e timeconsuming. Mas foi exatamente isso o que ocorreu com o Word 5.5, um upgrade do 5.0. Mudando a interface do programa (tornando-a compativel com a do Windows), e mantendo as mesmas funções do 5.0 , criou um descontentamento entre $2 / 3$ de seus usuários, muitos dos quais resolveram abandonar 0 Word e migrar para 0

- Word Perfect, fazendo com que a Microsoft perdesse mercado para seu maior concorrente nesse segmento. Seymour sintetiza esse erro estratégico da Microsoft na frase "Ela deu um tiro em seu próprio pé."

Obs.: No entanto, após o sucesso do Windows, os usuários terão necessariamente de se acostumar com a sua nova interface gráfica com mouse, abandonando os hábitos do modo texto do DOS.

48. *SEYMOUR, JIM. PCs and privacy issues. PC Magazine, Boulder, 10 (14):8990, Aug. 1991.

Os computadores estão sendo acusados de serem os principais instrumentos de violação das liberdades individuais e do direito à privacidade. Nossa renda mensal, endereço, propriedades, e outros dados pessoais estão passando de um para outro computador, através de malas-diretas, serviços de concessão de crédito, bancos etc., não se sabendo que tipo de uso esses dados podem estar tendo, nem se estão todos corretos. Uma medida imediata que Seymour propõe é não fornecer tais dados quando se recebe formulários para preencher. Diz 0 autor que, em 20 anos, ninguém reclamou do não preenchimento em $2 / 3$ dos casos, e nos $1 / 3$ restantes, quando solicitado a for- necê-los, ele sempre indagou "Para que vocês querem esses dados?", obtendo normalmente a resposta: "Oh! eu não sei... isso sempre constou dos formulários."

49. * SIMON, Barry. Squeeze play. PC Magazine, Boulder, 10 (17):291-2+, Oct. 15 1991.

Os arquivos podem geralmente ser comprimidos em até $70 \%$ de seu tamanho, reduzindo o custo da transmissão via modem, ou liberando mais espaço no disco. 0 artigo analisa seis programas de compressão, sugerindo LHA como o que mais comprime os arquivos, e PKZIP como o mais rápido.

Obs.: 0 Stacker (um dos programas mais vendidos) faz isso automaticamente (é residente).

50. * STINSON, Craig. Lotus 1-2-3 add-ins: building the perfect spredsheet. PC Magazine, Boulder, 10 (7):101-4, Apr. 161991.

A terceira maior aplicação dos micros são as planilhas eletrônicas e, dentre estas, a Lotus é a que domina o mercado, na proporção de 2:1. Embora não seja a planilha mais moderna e nem a de maiores recursos gráficos, seu sucesso se deve em parte à existência de uma miríade de fornecedores de programas que realizam funções não previstas na Lotus, mas que para o usuário é transparente: são os Addins (programas acessórios). A PCM analisa 21 Add-ins, tais como analisadores financeiros, controladores de orçamentos, simuladores de fluxo de caixa, realizadores de previsões financeiras, programação linear, otimizações em geral, e escolhe como os melhores: Financial Analyst, Financial Toolkit, ForeCalc e What-If Solver. Os Add-ins não são portáteis entre versões diferentes (um Add-in da versão 2 não roda na versão 3 nem na versão para o Windows), o que dificulta os upgrades (talvez por isso a versão 2.xx continue sendo a mais vendida nos EUA, a despeito de já ter sido lançada a versão 3 e a versão 1 para Windows).

51. ^STONE, M. David. Processor performance compared. PC Magazine, Boulder, $10(11): 157$, June 11 1991. (Ver tabela 5.)

52. *VENDITTO, Gus. Pipeline: a look at the trends shaping the personal computer market. PC Magazine, Boulder, 10 (20):29-30, Nov. 261991.

Duas pesquisas, entre 1.143 profissionais da Informática, mostraram que o DOS e a linguagem $\mathrm{C}$ são os preferidos para 0 desenvolvimento de aplicações. Os resultados podem ser observados nas tabelas 6 e 7 .

53. *ZACHMANN, William F. For once, a study worth studying. PC Magazine, Boul-

\section{Processor Performance Compared}

\begin{tabular}{|c|c|c|c|r|}
\hline proc & MHz & seg & vezes & US $\$$ \\
\hline 8088 XT & 4,8 & 32,9 & & 9 \\
\hline $286 \mathrm{AT}$ & 8 & 9,06 & 3,6 & 15 \\
\hline $386 \mathrm{SX}$ & 16 & 4,38 & 2,1 & 150 \\
\hline $386 \mathrm{DX}$ & 16 & 4,07 & 1,1 & 199 \\
\hline $386 \mathrm{SX}$ & 20 & 3,26 & 1,3 & 160 \\
\hline $386 \mathrm{DX}$ & 20 & 3,16 & 1,03 & 225 \\
\hline $386 \mathrm{DX}$ & 25 & 2,32 & 1,36 & 250 \\
\hline $386 \mathrm{DX}$ & 33 & 1,67 & 1,39 & 300 \\
\hline $486 \mathrm{DX}$ & 25 & 1,47 & 1,14 & 700 \\
\hline $486 \mathrm{DX}$ & 33 & 1,1 & 1,34 & 825 \\
\hline
\end{tabular}

Vezes=rapidez em relação ao modelo anterior, USS=preço do chip nos EUA em jul-91

\section{Para qual ambiente você desenvolve aplicações} (em \%)

\begin{tabular}{|l|r|}
\hline DOS & 90 \\
\hline Windows & 39 \\
\hline UNIX & 14 \\
\hline Mainframe/Minis & 8 \\
\hline Outros & 8 \\
\hline OS/2 & 7 \\
\hline Macintosh & 5 \\
\hline
\end{tabular}

Qual a linguagem usada
no desenvolvimento
(em \%)
\begin{tabular}{|l|r|}
\hline C & 51 \\
\hline BASIC & 44 \\
\hline Paradox & 36 \\
\hline Compativeis com dBase & 26 \\
\hline CC++e outras OOP & 26 \\
\hline PASCAL & 24 \\
\hline dBase & 22 \\
\hline Outras & 21 \\
\hline Macros para 123 & 20 \\
\hline Visual Basic (Windows) & 20 \\
\hline SQL & 14 \\
\hline COBOL & 12 \\
\hline FORTRAN & 9 \\
\hline Assembler & 7 \\
\hline
\end{tabular}


der, 10(11):97-8, June 111991.

Pesquisa feita nos EUA, mostra que 0 fator-chave de sucesso do Windows-3 (para $58 \%$ dos respondentes) não foram os aplicativos (Excel, PageMaker...) nem sua interface gráfica colorida, mas sim a habilidade de usar memória estendida. E 0 principal fator de fracasso da versão anterior ao 0S/2 2.0 foi a inabilidade de rodar aplicações DOS.

54. 'ZACHMANN, William F. Who controls PC acquisitions? PC Magazine, Boulder, 10 (7):95-6, Apr. 161991

Após breve análise, Zachmann conclui que "Na verdade, ninguém sabe", indicando a existência de um movimento de descentralização e democratização da Informática nas empresas americanas.

\section{0}

55. 1975-1990: 15 years of bits, bytes, and other great moments. Byte Magazine, $\mathrm{Pe}$ tersborough, 15:369-400, Sept. 1990.

Interessante artigo comemorativo, bem ilustrado, mostra a história da Informática, desde o lancamento do Altair 8800 , em 1975, considerado o primeiro microcomputador de uso comercial, passando pelo Apple e o PC, até os recentes laptops e palmtops. Em paralelo, acompanha também os lançamentos de softwares.

56. BARKER, C. Personal computing in Eastern Europe. Byte Magazine, Peterborough, 15:401-2+, Sept. 1990.

Descreve a situação de atraso em que se encontram os países comunistas, mostrando que em economias fechadas e reservadas a Informática não prospera. Como no Brasil.

57. BRADLEY, D.J. The criation of the IBM PC. Byte Magazine, Peterborough, 15:414+, Sept. 1990.

A história do PC da IBM, contada por um de seus criadores, cujo produto se tornou hoje um padrão mundial, a ponto de todos os outros similares fazerem questão de frisar que são IBM compativeis (leia-se copiado da IBM).

58. *DUNCAN, Ray. Power programming: a prescription for the operating system of the future. PC Magazine, Boulder, 9(18):395$98+$, Oct. 301990

DOS (Disk Operating System) é o sistema operacional mais utilizado no mundo inteiro. Vendeu 11 milhões de cópias em 1989, e a previsão para 1995 é de 100 milhões de cópias em uso. No entanto, o DOS não tem acompanhado a evolução que houve desde 0 lançamento do IBM-PC até os modernos IBM-PC-486. Duncan propõe várias melhorias para o DOS (algumas já incluídas na recente versão 5.0 de junho/91), mas outras, como a utilização dos recursos específicos dos microprocessadores 386486 (uso dos registros de 32 bits, que tornariam o DOS muito rápido), talvez só sejam implementadas em uma futura versão 6.0 (embora já existam no $0 S / 22.0$ ). De qualquer modo, o DOS ainda continuará sendo o sistema operacional padrão para os microcomputadores, a despeito da existência de outros três concorrentes: o UNIX da ATT (12\% do mercado, com bom desempenho em redes, mas sem recursos para controle em tempo-real e sem qualquer padronização), o 0 S/2 da IBM (ainda pouco usado), e o System 6 e 7 do Macintosh da Apple (com menos de $10 \%$ do mercado de micros e poucas chances de sucesso; a Apple se encontra em 1992 em negociações com a (BM). Pelas atuais tendências do mercado, talvez o caminho a ser seguido para os próximos anos seja o seguinte: DOS 5.0 (16 bits) e Windows 3.1 (16 bits), OS/2 2.0 da IBM (32 bits) ou Windows NT (32 bits) da Microsoft.

59. "DVORAK, John C. Copy protection nightmare. PC Magazine, Boulder, $9(9): 73$, May 151990.

Os esquemas de proteção das cópias contra pirataria de software não funcionam na prática, nem são aceitas pelos usuários. 0 Banco de Dados Paradox, ao ser lançado com proteção contra cópia, acabou sendo rejeitado, embora fosse um excelente produto. A empresa foi vendida para a Borland, que o relançou sem proteção contra pirataria. Os softwares protegidos são fontes de problemas de incompatibilidade com os sistemas operacionais, BIOS etc. sendo por isso rejeitados pelos usuários. A questão foi levantada porque, com a disseminação dos Notebooks, os usuários estão usando cópias de originais em seus portáteis, para o desagrado dos fabricantes de software.

Obs.: É interessante notar nas revistas americanas, na seção de anúncios, propaganda sobre firmas especializadas em esquemas de proteção contra cópias (antipirataria) e, ao lado, anúncios de softwares para efetuar cópias de programas protegidos ou para quebrar proteções (do tipo hard-lock, por exemplo, onde se coloca uma ROM na saída serial RS-232).

60. FORESTER, TOm \& MORRISON, Perry. $A$ insegurança do computador e a vulnerabilidade social. Op. cit. (Ver nota 38.)

61. *HOWARD, Bill. Printers: 7th Annual Special Issue. PC Magazine, Boulder, $g(19): 102$, Nov. 131990.

Neste artigo especial sobre impresso- ras, verifica-se que o mercado se encontra dividido entre $73 \%$ de impressoras de aguIhas e $27 \%$ de impressoras a laser, para um total de 6,42 milhões de unidades vendidas em 1989 . Ou $42 \%$ do faturamento para impressoras de agulhas e $58 \%$ para impressoras a laser, para um total de US\$ 6,2 milhões de vendas em 1989. Os principais fornecedores de impressoras de aguIhas foram: 1. Epson, 2. Panasonic, 3. Okidata. Para impressoras a laser: 1 . HewlettPackard, 2. Apple, 3. Panasonic. Como resultado do benchmark realizado pela PCM, as impressoras de agulhas selecionadas foram: Citizen GSX-140 (24 agulhas, US\$ 300 ), Citizen $200 \mathrm{GX}$ (9 agulhas, US\$200), Epson DFX-8000 ( 9 agulhas, trabalho pesado, US\$3.700), Epson LQ-850 e LQ-1050 (24 agulhas, US $\$ 750$ e US\$1.100) e NEC PinWriter P6200 e P6300 (24 agulhas, US $\$ 800$ e US $\$ 1.100)$. As impressoras a laser selecionadas como as melhores foram: HP LaserJet III (US\$1.600), LaserJet IIID (US\$2.800), IBM LaserPrinter $E$ (US\$1.000), NEC SilentWriter2-90 (US\$2.500) e QMS PS-2210 (US\$12.000).

62. KENNER, H. Stomping the nasties. Byte Magazine, Peterborough, 15:466, Nov. 1990.

Descreve os quatro tipos de invasores de micros: Worm (verme), um pequeno código inserido em um programa, que pode, por exemplo, fazer com que todo mês seja automaticamente transferida uma certa quantia para a conta bancária do autor do verme; Logic Bomb (bomba lógica), onde um funcionário despedido pode deixar inserida uma rotina em um sistema, de tal modo que dentro de dois meses todo o sistema seja destruído; Trojan Horse (Cavalo de Tróia), um programa com título sugestivo (por exemplo, Como acertar na loteria) mas que, ao ser executado, destrói os arquivos do disco; virus, que pode executar as mesmas funções dos três invasores acima, mas com uma característica adicional: a duplicação automática, isto è, vai infectando todos os disquetes que forem sendo inseridos no micro, os quais, por sua vez, vão introduzir 0 vírus em outros computadores, repetindo o processo (a duplicação também se dá através da rede onde $0 \mathrm{mi}$ cro se acha instalado). Após analisar alguns estragos causados pelos vírus em sistemas instalados nos EUA, Kenner sugere alguns remédios, como o Virus Scan da McAfee e o livro Computer Virus Handbook, da McGraw-Hill.

63. *MACHRONE, Bill. A practically perfect PC. PC Magazine, Boulder, 9(15):69-70, Sept. 111990.

Os cuidados a serem tomados ao adquirir computadores, principalmente os fabricados em fundos de quintal. Ressalta o rá- 
pido desenvolvimento do setor, afirmando que os convencionais métodos contábeis de depreciação para os computadores estão superados: um computador com um ano de lançamento já está obsoleto tecnologicamente.

64. *MENDELSON, Edward. Word processors: the best and the brightest. PC Magazine, Boulder, $9(21): 152$, Dec. 111990.

Um benchmark é realizado entre os processadores de texto à venda no mercado (a principal aplicação dos microcomputadores), pela revista PCM. Como Editor's Choice são selecionados o MS Word, AMI Professional, MS Word for Windows e Word Perfect, todos custando em torno de US\$ 500 . Este último domina mais que metade do mercado dos editores de texto.

65. *0'SHEA, Kathleen \& MURALIDHAR, Krishnamurty. The function and management of information centers. Journal of Systems Management, Cleveland, 41(12):7-9, Dec. 1990.

Os Centros de Informação têm mudado consideravelmente desde que a IBM inventou o termo em 1976. De acordo com um artigo de 1982 no IBM System Journal, quando John Hammond da IBM pela primeira vez descreveu os Centros de Informação, eram vistos como dedicado a dar suporte aos usuários dos sistemas de informações em atividades tais como geração de relatórios, análise e manipulação de dados, consultas espontâneas etc. 0 rápido desenvolvimento da tecnologia e a crescente sofisticação dos usuários finais ocasionou muitas mudanças no conceito de computação do usuário final, que provocou, por sua vez, mudanças no conceito de Centros de Informação. A facilitação da computação para os usuários finais tem permanecido como o objetivo principal dos Centros de Informação, mas novas idéias têm surgido com res-

\begin{tabular}{l} 
Porcentagem do tempo \\
dispendido pelos centros \\
de informações \\
\begin{tabular}{|l|r|}
\hline Hotline & 18 \\
\hline Treinamento do usuário & 16 \\
\hline Análise de situações & 16 \\
\hline Acesso a dados & 12 \\
\hline Programação aplicada & 9 \\
\hline Seleção de hard/software & 9 \\
\hline Desenvolvimento de sistemas & 7 \\
\hline Diversos & 6 \\
\hline Ligação micro-mainframe & 5 \\
\hline Gráficos & 2 \\
\hline
\end{tabular} \\
\hline
\end{tabular}

peito a como isto deve ser feito. 0 consenso entre vários pesquisadores hoje é de que 0 conceito original de Centro de Informações da IBM - o de treinamento e suporte para os usuários finais - deve ser revisto, através da evolução dos Centros de Informação e de mudanças organizacionais, para o novo conceito de administração da computação dos usuários finais. No nível prático, muitos Centros de informações estão ainda tentando definir e justificar sua posição na área da computação do usuário final. Esse artigo, procura mostrar, assim, através de uma pesquisa de campo, a situação em que se encontram os Centros de Informação nas empresas americanas. Um resultado interessante é destacado na tabela 8.

66. *PETZOLD, Charles. Environments: computing in the 1990's: why Windows 3.0 is only a short-term solution. PC Magazine, Boulder, $9(20): 469-72$, Nov. 271990.

Em 1980 surgiram os microprocessadores de 16 bits (8088), obsoletando os de 8 bits (Z80 e 8080). Houve também uma evolução no sistema operacional, com o DOS (16 bits) suplantando o CP/M (8 bits). Em fins de 80 , foram lançados os microprocessadores de 32 bits (386/486), mas continuaram em uso o DOS e o Windows (ambos de 16 bits), que não acompanharam a evolução do hardware. A alternativa seria o $0 \mathrm{~S} / 22.0$ ( 32 bits), mas a Microsoft, ao lançar 0 campeão de vendas Windows 3.0, acabou por eclipsar o OS/2. Assim, vemos hoje um microprocessador potente sendo usado apenas pela metade. Essa situação naturalmente não pode permanecer, pois seria 0 mesmo que a indústria automobilística começar a vender carros com seis cilindros, mas com apenas três velas de ignição. Petzold, dai conclui que o Windows + DOS é apenas uma solucão provisória. $0 \quad 0 S / 22.0$ (ou mesmo o UNIX, de 32 bits) deverão se impor com o tempo. A menos que a Microsoft lance um DOS 6.0 de 32 bits, seguido de um Windows 4.0 também de 32 bits. 0 grande problema é que, nesse caso, todas as aplicações anteriores (Lotus, Word, dBase etc.) não poderão mais rodar, devendo ser totalmente recodificadas para 32 bits, com seus altos custos de conversão.

67. SCHWARTZ, L.R. Promises, promises. Byte Magazine. Peterborough, 15:468, Nov. 1990.

0 autor, um promotor de Nova York adverte que, na prática, os Termos de Garantia existentes nos softwares adquiridos pelos usuários não têm qualquer valor, já que 0 fabricante se exime de qualquer responsabilidade pelas conseqüências maléficas advindas de um produto mal projetado, ou com erros de programação (bugs). 0 autor mostra que os advogados ainda não chegaram à conclusão se 0 comércio de software trata de vendas de serviço ou de vendas de bens de consumo, com a conseqüente dificuldade de enquadramento legal. Cita também casos de como os fabricantes tentam burlar as leis que dão ao consumidor certos direitos, dos quais eles não po-

\section{Tipo de PC utilizado nos} EUA ( $\%$ do total em uso)

\begin{tabular}{|l|r|}
\hline 386 & 43 \\
\hline $286(\mathrm{AT})$ & 37 \\
\hline $8088(\mathrm{XT})$ & 11 \\
\hline Outros (Macintosh etc.) & 9 \\
\hline
\end{tabular}

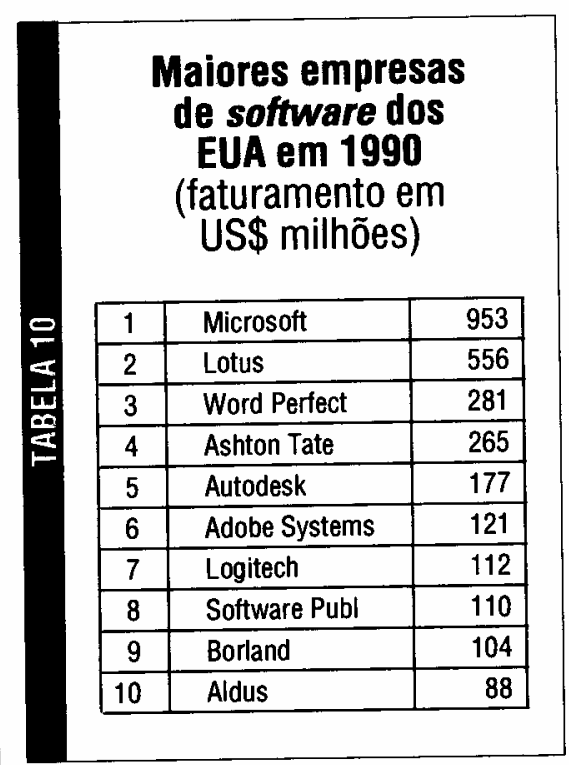

\section{Principal tipo de aplicação dada ao PC (\% das respostas)}

\begin{tabular}{|l|r|}
\hline Processamento de texto & 91 \\
\hline Banco de Dados & 73 \\
\hline Planilha Eletrônica & 71 \\
\hline Desenvolvimento de software & 51 \\
\hline Apresentações gráficas & 44 \\
\hline DeskTop Publishing & 43 \\
\hline CAD & 23 \\
\hline Pesquisa Científica & 21 \\
\hline Desenhos animados & 16 \\
\hline Projeto gráfico & 16 \\
\hline Controle de processo & 5 \\
\hline Outros & 2 \\
\hline
\end{tabular}


dem se desvencilhar (como o direito de devolução da mercadoria, por exemplo).

68. "VENDITTO, Gus. Pipeline. PC Magazine, Boulder, $9(11): 64$, June 12 1990.(Ver tabelas 9,10 e 11.)

69. `ZACHMANN, William F. Cost-justifying computers. PC Magazine, Boulder, g(17):93-4, Oct. 161990.

Em um artigo anterior, "Mainframe Machismo", Zachmann analisou a tendência de extinção dos tradicionais mainframes, criando naturalmente um impacto entre os profissionais de equipamentos de grande porte. Nesse artigo, o autor mostra que, não obstante os mainframes estejam com os dias contados, seus técnicos continuarão a ser requisitados, pois as novas plataformas, baseadas em redes de micros, necessitarão dos conhecimentos já utilizados no desenvolvimento de sistemas de grande porte, tais como dimensionamento de redes, projeto de banco de dados distribuído, seleção de hardware etc.

70. ${ }^{\star}$ ZACHMANN, William F. Mainframe machismo. PC Magazine, Boulder, 9(3):834, Feb. 131990.

Zachmann mostra que os mainframes estão com os dias contados. A'tendência são as redes de micros, por uma questão basicamente econômica: por que rodar um programa em equipamentos de milhões de dólares se um micro de mil dólares produz o mesmo resultado? Comenta também o fato de que as grandes corporações americanas estão despedindo seus executivos de mainframe, $\mathrm{e}$ substituindo-os por administradores de sistemas de menor porte, baseados em micros. Mas ainda existem os machistas do mainframe que acham que uma aplicação que roda em micro não é uma aplicação de verdade. 0 autor mostra que, no fundo, trata-se de uma reação a um semi-monopólio, já que o que caracteriza um mainframe não é propriamente seu tamanho, mas o fato de serem a arquitetura, o sistema operacional, os protocolos de comunicação e os softwares todos patenteados, com o resultante alto preço do sistema. Nos micros, ao contrário, existe a arquitetura aberta, 0 que permite que os IBM-PC sejam amplamente copiados, gerando os chamados IBM compatíveis e criando um mercado competitivo, com resultante redução do preço (exceção feita ao Macintosh que, por ser um monopólio - só há um fornecedor: a Apple - é caro e tem apenas $10 \%$ do mercado).

71. 'ZACHMANN, William F. Microsoft's "Window" to OS/2. PC Magazine, Boulder, $9(16): 89-90$, Sept. 251990.

Com o sucesso do lançamento do Windows 3.0, com mais de um milhão de cópias vendidas, muitos usuários conjectura- ram sobre a morte do $0 \mathrm{~S} / 2$, que se acreditava ser o sucessor do DOS. Zachmann mostra que isso é um engano. Ao contrário, o Windows será uma janela para a passagem do DOS para o OS/2. Houve, no entanto, uma série de desacertos entre a Microsoft e a IBM, com relação às estratégias de lançamento do Windows e do 0S/2, pois esta aparentemente se arrependeu de ter lançado o PC com arquitetura aberta (isto é, podendo ser copiada pelos concorrentes, o principal motivo do PC ter se tornado um padrão mundial) e teria tentado fechá-la novamente, através de um $0 \mathrm{~S} / 2$ patenteado, e do micro-channel (hardware também patenteado no PS/2). Um esquema semelhante é seguido pela IBM em seus mainframes (o sistema operacional MVS - Multiple Virtual System - é patenteado, bem como seu hardware). A Microsoft, por outro lado, seria partidária de arquiteturas e sistemas operacionais abertos.

\section{9}

72. ${ }^{\circ}$ VVORAK, John C. Dvorak's hall of infamy. PC Magazine, Boulder, 8(7):71, Apr. 111989.

Após discorrer sobre alguns produtos que fracassaram no mercado, como o software TopView da IBM, Lightning da Borland, planilha Jazz da Lotus, PCjr da IBM, Lisa e Apple III da Apple, chips 80186/188 e 8085 da Intel, 32032 da National e Z8000 da Zilog, editor de textos WordStar 2000, sistema operacional CPM-86, banco de dados R:Base, cartão Hércules InColor e outros, Dvorak lista oito maneiras seguras de fracassar:

1. Lance um produto inferior em um mercado onde já exista um similar de melhor qualidade;

2. Ignore as preferências do usuário e lance aquilo que você acha que os outros vão querer;

3. Use cocaína e decida com base na lógica induzida por ela;

4. Projete um produto que você não consiga construir;

5. Promova um produto novo e lance-o com anos de atraso;

6. Produza um produto que ninguém consiga explicar direito;

7. Dê um nome bobo a um bom produto;

8. Guarde segredo do produto, especialmente com relação à imprensa.

73. *NANOBYTES (Is it a revolution?). Byte Magazine, Peterborough, 14(5):16, May 1989.

Informa, baseado numa pesquisa entre 45.000 executivos americanos, que $70 \%$ não utiliza pessoalmente microcomputadores para a tomada de decisões. $E$, entre estes, apenas $9 \%$ pretende adquirir um no próximo ano. Os softwares destinados às decisões executivas são genericamente chamados de Sistemas de Apoio às Decisões.

\section{8}

74. AMIRREZVANI, A. Should you buy a service contract for your PC? PC World, San Francisco, 207, Apr. 1988.

Após analisar os custos, 0 autor conclui que não é interessante ter contratos de manutenção de micros. É mais barato chamar o técnico quando o problema ocorrer.

75. *MATTOS, Antonio Carlos M. "Reserva de mercado de Informática: o estado da arte". Revista de Administração de Empresas, São Paulo, 28(3):75-8, jul./set. 1988.

Mostra os resultados práticos da política protecionista de Informática em vigor no Brasil: equipamentos obsoletos vendidos a preços três vezes superiores à média internacional.

76. RYAN, C.R. "Measure the costs of PC ownership". PC World, San Francisco: 202+, Apr. 1988.

Apresenta uma metodologia para o cálculo dos custos de se ter um microcomputador.

\section{7}

77. ${ }^{*}$ HODGES, Parker. What are you worth? Datamation, Denver, 33(19):78+, 0ct.1 1987.

Descreve cargos, funções e salários do pessoal da área de Informática (mainframes). Os salários oscilam em torno de US\$ 61.000 /ano para vice-presidente, US $\$ 43.000$ para gerente de aplicações, US $\$ 22.021$ para analista de sistemas júnior e US $\$ 19.860$ para chefe dos operadores.

\section{8}

78. *MATTOS, Antonio Carlos M. "0 impacto do computador na empresa" Revista de Administração de Empresas, Rio de Janeiro, 18(4):53-8, out/dez. 1978.

Assim como no homem, também na empresa o sistema de informações constitui seu sistema nervoso, responsável pelo bom funcionamento e desempenho.

Assim, qualquer cirurgia realizada nessa rede provoca profundas alterações no comportamento da organização como um todo. É precisamente isso que ocorre quando um computador é introduzido. Atuando diretamente no sistema de informações existente, irá gerar inúmeras mudanças, algumas positivas, outras negativas. Entre as positivas, 0 artigo cita: aumento da capacidade da empresa de tra- 
tar suas próprias informações; rapidez na obtenção de informações; confiabilidade dos resultados; integração de subsistemas; deslocamento do poder na empresa; maior controle sobre a organização; economia; redução dos casos de suborno; símbolo de status; necessidade de planejamento.

Os impactos negativos citados são: submissão à máquina; diluição de responsabilidade; inflexibilidade e rigidez; deslocamento do poder para o CPD; poluição de informações; evasão de informações; temor de desemprego; possibidade de fraude; conflitos salariais; desorganização e ineficiência; conflito com o pessoal da área de Organização e Métodos.

\section{6}

79. *KORDA, Michael. 0 poder - como conquistá-lo, como utilizá-lo. São Paulo, Abril, 11 jul. 1976. 98p. (Exame, Edição Especial). KORDA, Michael. 0 jogo do poder nas empresas. Op. cit.

\section{JORNAIS}

\section{2}

80. CONSUMO de COBOL ainda é maior no Brasil. $O$ Estado de S. Paulo. São Paulo, 3 fev. 1992. Caderno de Informática, p.3

A tabela 12 mostra a participação em \% das famílias de linguagens de programação no faturamento da Microsoft no Brasil.

\section{OBSERVAÇÕES:}

\begin{abstract}
- Cobol
É a linguagem mais antiga (1960) para aplicaçōes administrativas (Folha de Pagamentos, Contabilidade etc.), tendo criado uma ampla base instalada no país. Como a conversão de programas em COBOL para outra linguagem é muito cara e demorada
\end{abstract}

(ou mesmo impossivel, se o programa não estiver documentado), os gerentes acabam preferindo permanecer com COBOL em suas instalações. É uma linguagem lenta, mas autodocumentável. Usada principalmente em computadores de grande porte. 0 COBOL mais usado é o da IBM e o da Microsoft.

- Assembler (ou Assembly, termo mais correto mas pouco usado)

É utilizada nos casos em que as linguagens não possuem os recursos necessários para uma dada aplicação (como em rotinas do sistema operacional). É a única que tem acesso a todos os recursos oferecidos pela $\mathrm{CPU}$ e a mais rápida. Os mais usados são 0 TASM da Borland e o MASM da Microsoft.

\section{- Fortran}

Criada em 1955, é utilizada em aplicações científicas e de engenharia. Vem sendo substituída por $C$. E uma linguagem bastante rápida.

\section{- Basic}

É uma linguagem para amadores, fácil de aprender. A Microsoft tem se esforçado para transformá-la em profissional (Quick C e Visual Basic, compiladas), tendo obtido sucesso com o Visual Basic (para Windows). Este interesse provavelmente se deve a que essa linguagem foi o primeiro produto oferecido pela Microsoft e o que a tornou conhecida. É muito utilizada em computadores pessoais. Os mais usados são 0 QuickBasic da Microsoft (vem junto com o DOS 5.0 e não é compilada) e o Visual Basic para Windows.

\section{- C ou C++}

É a linguagem por excelência dos programadores profissionais. É a mais rápida, só perdendo para 0 Assembler (em $\mathrm{C}_{++}$, as linguagens $C$ e Assembler podem ser misturadas em um mesmo programa). É utilizada em mais de $70 \%$ das soft-houses americanas. Se caracteriza pela portabilidade (é fácil transportá-la de uma instalação para outra), pela padronização (não há várias versões diferentes como no UNIX) e pela simplicidade (possui cerca de 10 ins- truções apenas). Foi criada por programadores para programadores. Para dominála, é necessário conhecer Assembler. Quase todos os softwares lançados hoje no mercado (Quattro, DBASE, Paradox, C, UNIX, Windows etc.) são programados em C. As mais usadas são o Turbo $\mathrm{C}$ e o C++ (OOP) da Borland e o C da Microsoft.

- Pascal (não mencionada no jornal) É utilizada em aulas, por ser fácil de ser ensinada. Possui razoáveis recursos, mas é lenta. É derivada do Algol francês. Alguns já a estão substituindo pela Modula-2, do mesmo autor. A mais usada é o Turbo Pascal da Borland.

- dBASE e Clipper (Borland e Nantucket, respectivamente)

São muito usadas em aplicações envolvendo Bancos de Dados em microcomputadores. Suas instruções são parecidas com Basic. São linguagens profissionais.

\section{8}

81. DIAS, R. "Equipamentos Vaporware são um vício nacional". Folha de $S$. Paulo, São Paulo, 29 jun. 1988. Caderno de Informática, p. B-3

Mostra os lançamentos nacionais, principalmente nas Feiras de Informática, que ou nunca chegam ao mercado ou demoram anos para aparecer.

\section{OBRA NÃO PUBLICADA}

\section{1}

82. GIANNINI, M. Centro de informações São Paulo, Nantucket do Brasil Ltda., 1991. n.p. (material não publicado)

Mauro Giannini, Diretor Técnico da Nantucket (Clipper), foi o responsável pela implantação de Centros de Informações em empresas brasileiras. Sua experiência no assunto foi transmitida através dessa apostila, onde se encontram temas como: a popularidade dos Cls e das linguagens de $4^{\mathrm{a}}$ geração, serviços oferecidos, relacionamento com usuários e com desenvolvimento de sistemas, direitos e deveres do usuário e do $\mathrm{Cl}$, implantação de um $\mathrm{Cl}$, gerência e avaliação de desempenho, funções e tarefas do $\mathrm{Cl}$, qualificação do pessoal do $\mathrm{Cl}$, gerenciamento de micros, packages para micros, redes locais (LANs), comunicação micromainframe, OOP (Object Oriented Programming), CASE (Computer Aided Software Engineering), inteligência artificial, EDI (Electronic Data Interchange) e UNIX-XENIX. $\square$ 